\title{
Environmental Case Study with regards to Water quality of Ancient wells of Bijapur.
}

\author{
Dr Geeta. S. Patil ${ }^{1}$, Dr S B Patil ${ }^{2}$, \\ ${ }^{1}$ Department of Botany, S B Arts and KCP Science college Bijapur, Karnataka India \\ ${ }^{2}$ Department of Chemistry S B Arts and KCP Science college Bijapur, Karnataka India
}

\begin{abstract}
Historic wells (boudies) built by Adil Shahi dynasty in Bijapur, are huge sources of water in drought area, presently neglected and polluted.The two wells Taj boudi and Chand boudi were selected to study the depth wise water quality physio-chemical, phytoplankton, and bacteriological study. In Taj Boudi exceptional vertical inverse thermal stratification was observed and in Chand Boudi homothermal condition was noted. The input of medical wastes in Chand Boudi, led to the release of biochemical parameters like creatinine, protein, glucose, urea and uric acid with the increase of E-coli. As a result, floating meadow formed by the mud and plaster of paris (idol material) has the growth of macrophytes which are nourished by the organic biochemical compounds decomposed by the bacterial activity which acts as manure for the macrophytes. The selfpurification of water takes place naturally as quality condition. Chlorides, nitrogenous content and carbon dioxide in the wells are high indicating rich nutritional status. There is natural symmetry expressed in the wells in the seasonal changes to the bacterio plankton and phyto plankton of water. Algal maxima were observed soon after which bacteria were in excess in Chand Boudi.
\end{abstract}

Keywords - Boudies, Natural Symmetry, Physico chemical, Phyto plankton, Thermal stratification.

\section{INTRODUCTION}

Water itself is an environment, supporting a large number of organisms. But this environment is being highly affected due to increased population, industrialisation and urbanisation which are tending towards scarcity of water to human race. The eutrophication of water, which in simplest sense means pollution of water or enrichment of nutrients and the resulting degradation of its quality accompanied by luxuriant growth of micro and macrophytes, is recognised as a major problem all around the globe.

The water studies of wells are very less in India. Pioneering works have been done on fresh waters but not wells. Hence the well study also becomes unique observation to know the impact of environmental factors on biotic components of water especially in depth profile.

The present work was undertaken in order to study the ecology of two ancient historical wells of Adil Shahis in Bijapur city. Bijapur - Ancient historical place of North Karnataka (India) was ruled by Adil Shahis. They have built huge wells with depth.

\subsection{Taj Boudi}

It is the largest well in Bijapur measuring $67 \mathrm{mts}$. in square and about $27 \mathrm{mts}$. in depth. It is named after Taj Sultana queen of Ibrahim Adil Shahi II. Formerly the water of this well was used for the drinking purpose and also for the irrigation of nearby lands. Till recently it was used for swimming but at present, due to the negligence and dumping of wastes idols of Ganesh and other Gods, water has become very dirty and is used for washing of clothes.

\subsection{Chand Boudi}

A beautiful well built by Adil Shahi VII and named after Chand Beebi a famous queen. Rectangular in shape with an era area of 1866 sq.mts, and a depth of $21.5 \mathrm{mts}$. The well is exposed to human disturbance, idols of Gods are dumped and it also receives the wastes of nearby hospital. A thick mat is formed due to the plaster of paris and other wastes. There is a growth of macrophytes over this mat- the floating meadow.

Today, Bijapur is a drought place with scarce rains. The geochemical and ecological conditions have become worse with heavy breezes of wind and with no top soil. Hence, the aim of the work is to study physical, chemical, biochemical, microbial and biological features of the well water.

The investigation of the water reveals the condition of water, the rich nutrients to give the picture of the ecology and ecosystem. Taj Boudi and Chand Boudi have seen exceptional temperature results of inverse thermal and homothermal stratification, the tolerant algae, in Chand Boudi - floating meadows of macrophytes and nature's purifying mechanism of water by circulation. 


\section{Materials and Method}

The collection of the water samples were made once in a month at fixed spots from October 2007 to September 2008. The collection of samples was made between 8.30 am to $9.30 \mathrm{am}$. Temperature was noted on the field and winklerisation was done on the spot. Other factors were analysed immediately in the laboratory on the same day without much lapse of time. The collection of samples at depth was done by using Van Dorn water sampler. All the physico-chemical parameters were analysed by the standard methods, 1980 and NEFRI. 1988 manual on water and waste water analysis. Surface water samples were collected for the microbial study in sterilized containers and given to the Dept. of Bio-Chemistry BLDEA's Medical College for the E-Coli tests. Samples of phytoplankton were collected from the surfaces and at various depths once in a month and the fixation and sedimentation were made $4 \%$ formalin and the supernatant was decanted.

\section{Results and Discussions}

The seasonal average values of the various variables in Taj Boudi and Chand Boudi are given in table I and.

\subsection{Water Temperature}

Water temperature range for the two wells was almost similar. Taj Boudi exhibited clear thermal stratification in summer and winter. There was a rare phenomenon observed of inverse thermal stratification in which the temperature of the deeper strata were higher than the upper layers. Both the water bodies experienced the high water temperature by the onset of monsoons. The reason may be due to the warming up of the rocky beds in summer and the rain waters flowing through these rocky beds will attain high temperature and cause a sudden increase in the temperature of the aquatic system.

\subsection{Taj Boudi - Temperature}

Temperature maxima were observed in the month of June and July at the surface. Heavy rains were recorded in these months and that may be the cause for the rise in temperature at the surface. December and January were cold with minimum temperature at the surface. A fluctuation of $7.80 \mathrm{C}$ was noted in the surface. Such low amplitude of thermal variation throughout the study is indicative of the tropical status of the water body $(1,2)$. Water temperature decreased from the surface to $9 \mathrm{mts}$ depth. A maximum difference of 30Cwas noted in the months of October and November between surface and 9 Mts. depth. Similar observations were supported by various authors $(3,4,5 \& 6)$. In February and March water temperature is constant at the surface240C, 3 mts- $230 \mathrm{C}, 6 \mathrm{mts}-230 \mathrm{C}$ and $9 \mathrm{mts}-220 \mathrm{C}$. This may be due to formation of thermal stratification which is observed in summer for tropical lakes (7).

An exceptional inverse thermal stratification has been attained in the months of December and January; the temperature has increased with the increase of depth $(8,9$, and 10$)$. This may be attributed to the formation of some chemical stratification where the increase in density due to the rise in temperature is not sufficient to overcome the increase due to the dissolved concentration (11). Thus in Taj Boudi, thermal stratification is observed and in few months it shows a rare phenomenon of inverse thermal stratification in which the temperature in the deeper strata is higher than the upper layers.

\subsection{Chand Boudi - Temperature}

Compared to Taj Boudi, Chand Boudi is a very shallow aquatic system. At the beginning of the study, water samples could be collected from surface $3 \mathrm{mts}$ and $4 \mathrm{mts}$ depth. From February onwards, the water level further decreased hence the samples from the surface and $3 \mathrm{mts}$ depth were only collected till the end of the study. Chand Boudi exhibited an average $25.880 \mathrm{C}$ with the range of 22.0-31.20C at $3 \mathrm{mts}$ and 23.0-27.00C at 4 mts. a very interesting phenomenon was noted in the month of March. The water temperatures recorded were the lowest $(230 \mathrm{C}$ at surface and $22.40 \mathrm{C}$ at $3 \mathrm{mts}$ ) compared to the temperatures of the remaining months. March is warm and the air temperature is high. Low temperature of water in the month of March can be explained by "Temperature Lag". Small water bodies respond quickly to the change in air temperature 7 \& 8. But Zafar 1968 (9) contends that water with thick global population or high salt content take much longer time to get heat and there will be a considerable temperature lag.

\subsection{Vertical Variation}

A decline of the temperature towards the lower strata was observed in the most of the months. Due to the swallow nature of the well, it exhibited homothermal conditions in the months of April, May, June, July, August and September. This mixing of water layers is the property of the swallow water body (10, 11 and 12). They have observed similar circulation in their studies. The growth of the macrophytes-typha must also have contributed to this type of thermal mixing (13). Thus Chand Boudi exhibited homothermal stratification due to the mixing of water layers in the well. 


\section{Physico-Chemical Parameters}

Hydrogen ion concentration for both the water bodies is on alkaline side. Taj Boudi did not show the presence of $\mathrm{CO} 2$ whereas in Chand Boudi the concentration was high. The observation indicates that the $\mathrm{pH}$ was controlled by carbonate and bicarbonate systems and in most of the time the equilibrium $\mathrm{CO}-, \mathrm{CO} 3$ - and $\mathrm{HCO} 3-$ was distributed. Free $\mathrm{CO} 2$ did not limit the $\mathrm{pH}$. This may be due to the large inputs of soaps and detergents. The study reveals that rains have caused the decrease in the concentrations of the above variables instead of dilution which is generally expected.

\subsection{Total alkalinity}

Total alkalinity dependent on the bicarbonate and carbonate concentration. Higher total alkalinity which was observed in Chand Boudi corresponds to high bicarbonate concentration due to the extensive washing of clothes and its shallow nature.

\subsection{Dissolved oxygen}

Dissolved oxygen concentration was not dependent on water in Taj Boudi whereas in Chand Boudi deeper strata exhibited inverse relation. Taj Boudi exhibited very low concentration of DO compared to Chand Boudi. This may be due to the stratified nature. In Chand Boudi average concentration indicate that oxygen was more at lower strata. $\mathrm{pH}$ also varied directly with DO indicating oxygen liberated during the photosynthesis and free carbon dioxide will consumed ultimately increases the $\mathrm{pH}$ values.

\subsection{Nitrogenous contents}

Nitrogenous contents of both the wells are very high indicating rich nutritional status. Free ammonia concentration in Taj Boudi was high at $9 \mathrm{mts}$ depth whereas in Chand Boudi the surface water had high concentration. Free ammonia and nitrate were not significantly related except at few strata in Chand Boudi, indicating the source of nitrate was probably the allochthonous material rather than by the oxidation of ammonia.

\subsection{Cationic concentrations}

Cationic concentrations of both the wells have shown very high values and were in the order of $\mathrm{Na}>\mathrm{K}>\mathrm{Mg}>\mathrm{Ca}$ in Chand Boudi and in Taj Boudi it was in the order of $\mathrm{Na}>\mathrm{Mg}>\mathrm{K}>\mathrm{Ca}$. An unusual concentration of $\mathrm{Mg}$ has been observed in both the wells. Chand Boudi contains high concentrations of $\mathrm{Na}+$ and $\mathrm{K}+$ this may be due to senescing shoots of emerging macrophytes (14).

\subsection{Chloride concentration}

Chloride concentration was very high in both the wells indicating high level of pollution of animal origin. Monsoon periods exhibited high values and the amplitude of variation in both the wells was similar. Monsoon rains have caused a general increase in the concentration, instead of dilution and sometimes dilution was observed in summer period, which may be due to the addition of underground water through springs.

\subsection{Hardness of water}

Hardness of water bodies was not dependent on chloride, sodium or potassium, but it was related with magnesium like carbohydrates, bicarbonates, hydroxides, sulphates, etc... The higher the hardness values imparted the water with high buffer action and hence the water bodies with high hardness have exhibited low amplitude of variation of $\mathrm{pH}$.

\subsection{Silica concentration}

Silica concentration in general was temperature dependent. High temperatures increased the silica concentration by which we can conclude that silica will be diffused into the water and will be distributed to all the strata in waters. Higher silica concentration has corresponded to increase in $\mathrm{pH}$ values. This confirms the reported literature in which the hydrolysis of silica which gives rise to silicic acid contributes to the rise in $\mathrm{pH}$.

\section{Phytoplankton}

The study of phytoplankton ecology contributes to an understanding of the basic nature and general economy of the fresh water body. Generally a lake or a water body is considered as an ecological complex of a very high order or more briefly as an "Ecosystem" composed of biotopes and biocoenosis. However in spite of all the factors, the phytoplankton co-exist in a community and probably such is balanced more so in the tropical waters, whereas seasonal variations are not significant. 
In the present study, the chlorococcales, desmidiales, euglenophyceae, bacillariophyceae and cyanophyceae were recorded with peculiar feature of adaptability. Some species of the phytoplankton showed their maximum tolerance to the pollution of the water of two of the wells is highly rich with nutrients and other chemicals, organic, inorganic and bio-chemical complexes.

A study on occurrence of few chlorococcales species in the different ranges of abiotic factors revealed that Scenedesmus dimorphus and S.arcuatus had the highest tolerance.

Desmids are considered to be strict aquatic fresh water algae, unable to withstand even apparently negligible in the quality of the aquatic habitat. The desmids had lesser periodicity in the present study. In general they were confined to the upper strata of the water column in the Taj Boudi and they were absent in Chand Boudi.

In the present study, some taxa of the desmids however showed their pollution tolerant nature. Of the six species, three species were with constant tolerance with high temperatures and alkaline $\mathrm{pH}$. The study also indicated that Cosmarium margaritatium, C. laeve and C. Crenatum are highly pollution tolerant desmids.

The volvocales were very poorly represented by a single species of The euglenophyceae represent a very sensitive group of flagellates and are the algae of hot season. They do not show their peculiar behaviour towards physico-chemical factors and other complexes are known for their occurrence in polluted waters and are dwellers of eutrophic waters rich in organic content.

In general, Euglena proxima and Tracelomonas volvocina were distributed in both the habitats.

The cyanophyceae are highly successful group and enjoy wide distribution in all kinds of habitats. They are probably predominant among the aboriginal organisms on the earth and are important both qualitatively and quantitatively. The present study shows that most of the nutrients increase during rains. Possibly Cyanophycean members utilize these nutrients during winter and increase in their population. The constant occurrence of Oscillators princes, Microcystis aeruginosa, Raphidiopsis and Anabaenopsis is an indication that the wells are all highly eutrophicated. These above taxa were highly resistant to various nutrient increases.

The diatoms are the most flexible organisms showing a wide range of adaptability. The diatoms also became predominant and resistant even in the organically rich water.

\section{Bio-Chemical And Bacteriological Studies}

The bacterioplankton population was studies with more importance to the count of Escherichia coli (Ecoli) as indicator of bacteria. As the wells are very old, lot of organic matter has been accumulated in water. Hence the water samples showed the presence of E-coli. These bacteria are the faecal bacteria present in the water contaminated by the sewage. Their mere presence itself indicates that the water body is polluted.

In Taj Boudi, E-coli count was at an annual average of 1359/100ml. in the month of October and from January onwards to September, the bacterial counts were highest up to 1800/100 ml. In Chand Boudi, E-coli were maximum counting up to $1408.7 / 100 \mathrm{ml}$ on a yearly average. Their maximum was in summer and decreased in winter and monsoon. In the month of October and January onwards they increased tremendously in number. Bio-chemical characters like glucose, protein, urea, uric acid and creatinine which occur rarely in the well water have been observed in these historic wells. Similar observation war made by Venkateshwaralu et al (1990) (15) in which they have assessed physio-chemical, biological (phycological and bacteriological) and biochemical aspects of river Moosi to assess water pollution.

The source of bio-chemical substances like glucose and proteins, according to various reports are algal derivatives. Algae release extracellular organic compounds like glucose, protein, starch, cellulose and many other similar organic complexes which act as substrate for the bacterial growth (16).

The bacterioplankton and phytoplankton population were studied in relation with temperature, oxygen, dissolved organic matter and $\mathrm{pH}$ other bio-chemical compounds like glucose, protein, urea, uric acid and creatinine were also studied.

Temperature- In Taj Boudi the optimum temperature for their growth in summer was $26.5 \square \mathrm{C}$ and in Chand Boudi $26.3 \square \mathrm{C}$. Bacteria are sensitive to variations in $\mathrm{pH}$. They grow in the natural or alkaline medium. In Taj Boudi, $\mathrm{pH}$ for E-coli growth in summer was 7.8 and in Chand Boudi it was 8.1 which have favoured high growth.

Dissolved Organic Matter- Increased mineralization of the organic matter induces primary production and increases particulate organic carbon (17). The two wells had high dissolved organic matter congenial for the growth of bacteria. From all the research works it is a known fact that, glucose is the most essential nutrient for the bacteria (17). Glucose is the end compound of photosynthetic activity by the planktonic algae. This is a natural substrate for bacteria.

In Chand Boudi, glucose and urea were more observed with protein, uric acid and creatinine. Hence the excess of glucose and urea along with others increased the growth of E-coli. When compared to Taj Boudi, Chand Boudi is conspicuously favourable for the growth of bacteria as the autochthonous organic material is 
increased due to the "floating meadow" supported by Rai (1979). Both allochthonous organic material added from the external source of hospitals autochthonous waste have increased growth of bacteria. In Taj Boudi, the phytoplanktonic algae are observed to be coinciding with the bacterial density. This conincidence of summer maxima of bacteria and phytoplankton suggests a closed interaction between phytoplankton and bacterioplankton (Oswald 1973). The algae supply the necessary factors for the growth of bacteria. In Chand Boudi, however the bacteria alternated with the algal growth and bloom.

On the whole, there is a beautiful and natural symmetry expressed in the biological science between the seasonal changes to the bacterioplankton and the phytoplankton of water. Thus in the present study, both the groups algae and bacteria were resistant to the environmental fluctuations. Closely coupled by the competitions, mutual separation and support. At this stage sensitivity of the ecosystem of environmental factor greatly declines and dynamic equilibrium in supported chiefly by the biotic interactions between the dominant organisms.

Thus the dominancy of E-coli in open wells clearly indicates the susceptibility of these wells to contamination. It is indicated that while coliform may die rapidly in clean streams, they can increase in numbers in polluted streams. Thus it seems that the high enrichment with organic matter provided a major of stabilization to this ecosystem.

\section{Conclusion}

Water quality and limnological studies of two fresh water habitats has revealed the nature's most interesting phenomenonof physio-chemical, bio-chemical, phyto $\&$ bacterio planktonic structure to give the picture of the ecology and ecosystem. Ancient wells of Bijapur, Taj Boudi and Chand Boudi have seen exceptional temperature results of inverse thermal vertical stratification and homothermal stratification. The pytoplanktonic study has shown the pollution indicators like cyanophyceae and diatoms. Pollution tolerance is seen by the occurrence of Desmids (Fresh water indicators) which is of rare kind. The co-existence of algal bloom with the bacteria-Ecoli in Chand Boudi has the resultant assistance for the "floating meadow" of macrophytes. In this process, there is nature's purifying mechanism of water by circulation and oxygenating.

As Bijapur is a drought place in the Deccan plateau, the water of old wells can be used for recreation, gardening and converted into portable water. The heritage of Adil Shahis, thus can be protected and conserved with its natural source- WATER.

\section{Acknowledgement}

The authors are thankful to the Management of BLDE Association, Bijapur and to the UGC for providing financial assistance.

\subsection{Table I}

\section{TABLES}

Seasonal average values of Physico-Chemical factors of Taj Boudi

\begin{tabular}{|c|c|c|c|c|c|c|c|c|c|c|c|c|c|}
\hline \multirow{2}{*}{$\begin{array}{l}\text { Seasons } \\
\text { Sl. No }\end{array}$} & \multirow[b]{2}{*}{ Factors } & \multicolumn{4}{|c|}{ WINTER } & \multicolumn{4}{|c|}{ SUMMER } & \multicolumn{4}{|c|}{ MONSOON } \\
\hline & & Surface & $\begin{array}{l}3 \\
\mathrm{mt}\end{array}$ & $\begin{array}{l}6 \\
\mathrm{mt}\end{array}$ & $\begin{array}{l}9 \\
\mathrm{mt}\end{array}$ & Surface & $\begin{array}{l}3 \\
\mathrm{mt}\end{array}$ & $\begin{array}{l}6 \\
\mathrm{mt}\end{array}$ & $\begin{array}{l}9 \\
\mathrm{mt}\end{array}$ & $\begin{array}{l}\text { Surfa } \\
\text { ce }\end{array}$ & $\begin{array}{l}3 \\
\mathrm{mt}\end{array}$ & $\begin{array}{l}6 \\
\mathrm{mt}\end{array}$ & $\begin{array}{l}9 \\
\mathrm{mt}\end{array}$ \\
\hline 1. & $\begin{array}{l}\text { Water } \\
\text { Temp }\end{array}$ & 26.27 & $\begin{array}{l}26 . \\
7\end{array}$ & $\begin{array}{l}26 . \\
75\end{array}$ & $\begin{array}{l}27 . \\
5\end{array}$ & 26.5 & $\begin{array}{l}25 . \\
5\end{array}$ & $\begin{array}{l}25 . \\
5\end{array}$ & $\begin{array}{l}29 . \\
0\end{array}$ & 28.52 & $\begin{array}{l}28 . \\
0\end{array}$ & $\begin{array}{l}27 . \\
25\end{array}$ & - \\
\hline 2. & $\mathrm{pH}$ & 8.107 & $\begin{array}{l}8.1 \\
35\end{array}$ & $\begin{array}{l}8.1 \\
0\end{array}$ & $\begin{array}{l}8.1 \\
25\end{array}$ & 7.8 & 7.9 & $\begin{array}{l}8.0 \\
75\end{array}$ & $\begin{array}{l}8.8 \\
5\end{array}$ & 8.975 & $\begin{array}{l}8.9 \\
5\end{array}$ & $\begin{array}{l}9.0 \\
25\end{array}$ & - \\
\hline 3. & $\begin{array}{l}\text { Carbon } \\
\text { dioxide }\end{array}$ & - & - & - & - & - & - & - & - & - & - & - & - \\
\hline 4. & Carbonate & 31.2 & $\begin{array}{l}30 . \\
55\end{array}$ & $\begin{array}{l}30 . \\
6\end{array}$ & $\begin{array}{l}30 . \\
0\end{array}$ & 30.0 & $\begin{array}{l}33 . \\
6\end{array}$ & $\begin{array}{l}35 . \\
10\end{array}$ & $\begin{array}{l}25 . \\
20\end{array}$ & 31.8 & $\begin{array}{l}34 . \\
8\end{array}$ & $\begin{array}{l}34 . \\
8\end{array}$ & - \\
\hline 5. & $\begin{array}{l}\text { Bi- } \\
\text { Carbonate }\end{array}$ & 236.0 & $\begin{array}{l}22 \\
9.1\end{array}$ & $\begin{array}{l}23 \\
4.8\end{array}$ & $\begin{array}{l}23 \\
3.0\end{array}$ & 327.4 & $\begin{array}{l}34 \\
2.7 \\
7\end{array}$ & $\begin{array}{l}34 \\
0.9 \\
5\end{array}$ & $\begin{array}{l}30 \\
2.5\end{array}$ & $\begin{array}{l}402.5 \\
5\end{array}$ & $\begin{array}{l}35 \\
3.2\end{array}$ & $\begin{array}{l}29 \\
5.1\end{array}$ & - \\
\hline 6. & $\begin{array}{l}\text { Tot- } \\
\text { Alkalinity }\end{array}$ & 245.5 & $\begin{array}{l}24 \\
2.5\end{array}$ & $\begin{array}{l}24 \\
3.5\end{array}$ & $\begin{array}{l}24 \\
4.1\end{array}$ & 323.5 & $\begin{array}{l}33 \\
7.0 \\
0 \\
\end{array}$ & $\begin{array}{l}33 \\
8.0 \\
0 \\
\end{array}$ & $\begin{array}{l}29 \\
0.0 \\
0 \\
\end{array}$ & 387.5 & $\begin{array}{l}34 \\
7.5\end{array}$ & $\begin{array}{l}30 \\
0.0\end{array}$ & - \\
\hline 7. & D.O. & 3.45 & 3.7 & $\begin{array}{l}3.1 \\
5 \\
\end{array}$ & $\begin{array}{l}2.8 \\
3 \\
\end{array}$ & 2.85 & $\begin{array}{l}2.5 \\
5 \\
\end{array}$ & $\begin{array}{l}3.0 \\
0 \\
\end{array}$ & $\begin{array}{l}0.9 \\
0 \\
\end{array}$ & 5.15 & 3.8 & 2.5 & - \\
\hline 8. & Org. Matter & 7.415 & $\begin{array}{l}7.9 \\
03\end{array}$ & $\begin{array}{l}8.1 \\
67\end{array}$ & $\begin{array}{l}10 . \\
14\end{array}$ & 12.37 & $\begin{array}{l}11 . \\
39\end{array}$ & $\begin{array}{l}10 . \\
41\end{array}$ & $\begin{array}{l}13 . \\
00\end{array}$ & 5.00 & $\begin{array}{l}6.6 \\
0\end{array}$ & 6.5 & - \\
\hline
\end{tabular}


Environmental Case Study with regards to Water quality of Ancient wells of Bijapur.

\begin{tabular}{|c|c|c|c|c|c|c|c|c|c|c|c|c|c|}
\hline 9. & Chlorides & 566.9 & $\begin{array}{l}55 \\
6.4 \\
\end{array}$ & $\begin{array}{l}55 \\
8.9 \\
\end{array}$ & $\begin{array}{l}56 \\
5.9 \\
\end{array}$ & 469.5 & $\begin{array}{l}46 \\
1.5 \\
\end{array}$ & $\begin{array}{l}47 \\
0.0\end{array}$ & $\begin{array}{l}46 \\
6.5 \\
\end{array}$ & 577.9 & $\begin{array}{l}55 \\
1.9 \\
\end{array}$ & $\begin{array}{l}52 \\
6.9 \\
\end{array}$ & - \\
\hline 10. & Hardness & 806.5 & $\begin{array}{l}79 \\
4.5\end{array}$ & $\begin{array}{l}79 \\
3.0\end{array}$ & $\begin{array}{l}76 \\
8.8 \\
0\end{array}$ & 693.5 & $\begin{array}{l}70 \\
7.0\end{array}$ & $\begin{array}{l}71 \\
8.5\end{array}$ & $\begin{array}{l}76 \\
2.0\end{array}$ & 521.5 & $\begin{array}{l}48 \\
3.0\end{array}$ & $\begin{array}{l}43 \\
1.0\end{array}$ & - \\
\hline 11. & Calcium & 17.45 & $\begin{array}{l}16 . \\
90\end{array}$ & $\begin{array}{l}16 . \\
55\end{array}$ & $\begin{array}{l}16 . \\
05\end{array}$ & 29.50 & $\begin{array}{l}23 . \\
42\end{array}$ & $\begin{array}{l}18 . \\
97\end{array}$ & $\begin{array}{l}14 . \\
15\end{array}$ & 30.30 & $\begin{array}{l}28 . \\
77\end{array}$ & $\begin{array}{l}26 . \\
02\end{array}$ & - \\
\hline 12. & Magnesium & 186.9 & $\begin{array}{l}18 \\
7.4\end{array}$ & $\begin{array}{l}18 \\
8.4\end{array}$ & 18 & 163.4 & $\begin{array}{l}16 \\
7.3\end{array}$ & $\begin{array}{l}17 \\
1.3\end{array}$ & $\begin{array}{l}18 \\
0.9\end{array}$ & 115.4 & $\begin{array}{l}11 \\
0.9\end{array}$ & $\begin{array}{l}98 . \\
4\end{array}$ & - \\
\hline 13. & Silica & 3.00 & $\begin{array}{l}2.8 \\
0\end{array}$ & $\begin{array}{l}2.5 \\
0\end{array}$ & $\begin{array}{l}1.5 \\
0\end{array}$ & 5.00 & $\begin{array}{l}3.5 \\
0\end{array}$ & $\begin{array}{l}3.3 \\
0\end{array}$ & $\begin{array}{l}2.0 \\
0\end{array}$ & 6.57 & $\begin{array}{l}6.5 \\
0 \\
\end{array}$ & $\begin{array}{l}6.5 \\
0\end{array}$ & - \\
\hline 14. & Free Amm. & 5.39 & $\begin{array}{l}5.2 \\
5 \\
\end{array}$ & $\begin{array}{l}4.9 \\
3 \\
\end{array}$ & $\begin{array}{l}5.0 \\
0 \\
\end{array}$ & 2.35 & $\begin{array}{l}2.4 \\
75 \\
\end{array}$ & $\begin{array}{l}2.2 \\
72 \\
\end{array}$ & $\begin{array}{l}2.8 \\
0 \\
\end{array}$ & 1.425 & $\begin{array}{l}1.7 \\
25\end{array}$ & $\begin{array}{l}2.0 \\
02 \\
\end{array}$ & - \\
\hline 15. & $\begin{array}{l}\text { Org. } \\
\text { Nitrogen } \\
\end{array}$ & 5.023 & $\begin{array}{l}5.3 \\
50 \\
\end{array}$ & $\begin{array}{l}5.0 \\
75 \\
\end{array}$ & $\begin{array}{l}5.0 \\
75 \\
\end{array}$ & 1.475 & $\begin{array}{l}1.3 \\
75 \\
\end{array}$ & $\begin{array}{l}0.6 \\
45 \\
\end{array}$ & $\begin{array}{l}1.3 \\
00 \\
\end{array}$ & 1.470 & $\begin{array}{l}2.8 \\
50 \\
\end{array}$ & $\begin{array}{l}3.6 \\
45 \\
\end{array}$ & - \\
\hline 16. & $\begin{array}{l}\text { Phosphorou } \\
\mathrm{s}\end{array}$ & 0.85 & $\begin{array}{l}1.1 \\
75 \\
\end{array}$ & $\begin{array}{l}0.8 \\
9 \\
\end{array}$ & $\begin{array}{l}0.0 \\
8 \\
\end{array}$ & 1.825 & $\begin{array}{l}1.7 \\
50 \\
\end{array}$ & $\begin{array}{l}1.1 \\
75 \\
\end{array}$ & $\begin{array}{l}0.3 \\
5 \\
\end{array}$ & 1.95 & $\begin{array}{l}2.1 \\
25 \\
\end{array}$ & $\begin{array}{l}2.1 \\
0 \\
\end{array}$ & - \\
\hline 17. & Nitrate & 4.65 & 4.9 & 5.2 & 5.5 & 2.9 & 3.5 & 3.3 & 3.3 & 3.67 & $\begin{array}{l}4.3 \\
7 \\
\end{array}$ & $\begin{array}{l}4.5 \\
2 \\
\end{array}$ & - \\
\hline 18. & Sodium & 408.06 & $\begin{array}{l}42 \\
0.1 \\
3 \\
\end{array}$ & $\begin{array}{l}41 \\
9.5 \\
6 \\
\end{array}$ & $\begin{array}{l}41 \\
3.8 \\
1 \\
\end{array}$ & 381.63 & $\begin{array}{l}38 \\
1.5 \\
0 \\
\end{array}$ & $\begin{array}{l}38 \\
0.6 \\
2 \\
\end{array}$ & $\begin{array}{l}39 \\
0.8 \\
3 \\
\end{array}$ & $\begin{array}{l}382.8 \\
2\end{array}$ & $\begin{array}{l}37 \\
3.5\end{array}$ & $\begin{array}{l}37 \\
2.4\end{array}$ & - \\
\hline 19. & Potassium & 135.86 & $\begin{array}{l}13 \\
7.4 \\
1 \\
\end{array}$ & $\begin{array}{l}14 \\
9.3 \\
3 \\
\end{array}$ & $\begin{array}{l}16 \\
0.1 \\
6 \\
\end{array}$ & 96.96 & $\begin{array}{l}95 . \\
71\end{array}$ & $\begin{array}{l}10 \\
4.1 \\
0 \\
\end{array}$ & $\begin{array}{l}15 \\
6.9 \\
7 \\
\end{array}$ & 50.69 & $\begin{array}{l}51 . \\
80\end{array}$ & $\begin{array}{l}67 . \\
07\end{array}$ & - \\
\hline
\end{tabular}

8.2. Table II

Seasonal average values of Physico-Chemical factors of Chand Boudi

\begin{tabular}{|l|l|l|l|l|l|l|l|l|}
\hline $\begin{array}{l}\text { Season } \\
\mathrm{s}\end{array}$ & \multicolumn{3}{|l|}{ WINTER } & \multicolumn{3}{l|}{ SUMMER } & \multicolumn{2}{l|}{ MONSOON } \\
\hline Sl. No & Factors & Surface & $3 \mathrm{mt}$ & $4 \mathrm{mt}$ & Surface & $3 \mathrm{mt}$ & Surface & $3 \mathrm{mt}$ \\
\hline 1. & $\begin{array}{l}\text { Water } \\
\text { Temp }\end{array}$ & 26.25 & 25.12 & 24.75 & 26.25 & 25.82 & 28.55 & 28.3 \\
\hline 2. & pH & 8.155 & 8.05 & 8.15 & 8.15 & 8.10 & 9.025 & 8.45 \\
\hline 3. & $\begin{array}{l}\text { Carbon } \\
\text { dioxide }\end{array}$ & 55.91 & 56.912 & 55.89 & 67.9 & 65.9 & 53.90 & 50.40 \\
\hline 4. & $\begin{array}{l}\text { Bi- } \\
\text { Carbonate }\end{array}$ & 662.39 & 684.40 & $\begin{array}{l}686.2 \\
1\end{array}$ & 818.57 & 795.40 & 641.07 & 616.07 \\
\hline 5. & $\begin{array}{l}\text { Tot- } \\
\text { Alkalinity }\end{array}$ & 543.00 & 561.00 & $\begin{array}{l}563.2 \\
5\end{array}$ & 671.00 & 652.00 & 525.50 & 505.00 \\
\hline 6. & D.O. & 1.80 & 2.25 & 2.85 & 3015 & 3.95 & 2.55 & 3.15 \\
\hline 7 & Org. Matter & 3.849 & 2.632 & 2.512 & 6.06 & 3.06 & 5.00 & 7.00 \\
\hline 8. & Chlorides & 378.34 & 371.84 & 388.8 & 469.5 & 461.5 & 577.9 & 551.9 \\
\hline 9. & Hardness & 657.00 & 647.50 & $\begin{array}{l}620.0 \\
0\end{array}$ & 593.00 & 546.00 & 523.00 & 530.00 \\
\hline 10. & Calcium & 15.00 & 16.77 & 15.65 & 13.00 & 11.77 & 14.77 & 15.30 \\
\hline 11. & Magnesium & 153.94 & 153.68 & 145.8 & 136.87 & 126.00 & 121.75 & 123.00 \\
\hline 12. & Silica & 4.50 & 7.00 & 4.00 & 3.00 & 3.50 & 4.00 & 7.00 \\
\hline 13. & Free Amm. & 1.43 & 1.24 & 1.17 & 2.65 & 2.35 & 6.95 & 6.17 \\
\hline 14. & $\begin{array}{l}\text { Org. } \\
\text { Nitrogen }\end{array}$ & 4.22 & 3.57 & 3.77 & 4.65 & 4.55 & 6.00 & 5.1 \\
\hline 15. & $\begin{array}{l}\text { Phosphoro } \\
\text { us }\end{array}$ & 1.62 & 1.05 & 1.92 & 2.31 & 2.65 & 2.55 & 2.85 \\
\hline 16. & Nitrate & 2.35 & 2.825 & 3.00 & 3.45 & 4.25 & 2.4 & 5.45 \\
\hline 17. & Sodium & 440.25 & 447.58 & $\begin{array}{l}449.4 \\
5\end{array}$ & 436.80 & 420.71 & 356.34 & 388.53 \\
\hline 18. & Potassium & 59.33 & 59.42 & 65.68 & 65.00 & 59.92 & 62.94 & 65.50 \\
\hline
\end{tabular}


Environmental Case Study with regards to Water quality of Ancient wells of Bijapur.

8.3. TABLE III

Seasonal Distribution of Algae and Bacteria

\begin{tabular}{|l|l|l|l|l|l|l|}
\hline Plankton & \multicolumn{2}{|l|}{ Taj Boudi } & Chand Boudi & \multicolumn{2}{l|}{} \\
\hline & Winter & Summer & Monsoon & Winter & Summer & Monsoon \\
\hline Algae & 676.7 & 7035.6 & 1406.9 & 1951.8 & 302.6 & 815.1 \\
\hline Bacteria & 1237.5 & 1800.0 & 1425.0 & 1350.0 & 1800.0 & 1500.0 \\
\hline
\end{tabular}

8.3.1. Annual average of algae and bacteria

\begin{tabular}{|l|l|l|}
\hline Plankton & Taj Boudi & Chand Boudi \\
\hline Algae & 2,924 & 1,025 \\
\hline Bacteria & 19,650 & 20,200 \\
\hline
\end{tabular}

\section{REFERENCES}

\section{Journal Papers:}

[1] HUTCHINSON, G.E. 1975 A. Treatise on Lymnology, Vol II. John Wiley and Sons, New York.

[2] JANA, B.B. 1979 Temporal Plankton Succession and Ecology of a Tropical Tank In West Bengal. Int. Reve. Ges. Hydrobiol. 64: 661-671

[3] SPURR B. 1975 Lymnology of BirdPondRossIslandAntarctica N.Z.J. Marland Fresh Water Res, 2 (4): $547-572$

[4] KHAN. M. A \& D.P.ZUTSHI,1980 Primary Productivity \& tropic status of KashmirHimalayanLake Hydro-Biologia 68-38

[5] JYOTI. M. K, H.S. SEHGAL \& P.S.SODHI 1986 Thermal Ecology of Surinsar. A Sub-Tropical Fresh Water lake In Jammu, India. Polskie Archiwum Hydro-Biologia 33 (1): 9-20

[6] KAUL.V.J.K. HANDOO R. Raina, 1980 Physio-Chemical characteristics of Nilang- A High Altitude forest Lake In Kashmir. Proc. Indian Nat Sci Acad B 16 (4). 528-541

[7] MUNAWAR.M. and A.R.ZAFAR, 1967. Apreliminary study of vertical Movement of Eudorina elegans during a bloom caused by them. Hydrobiologia. 29(1-2):140-148.

[8] ZAFAR.A.R. 1968 .Certain Aspects of Distribution Pattern of Phytoplankton in the lakes of Hyderabad. Proc. Symp. Recent Adv. Trop. Ecol: 368-375

[9] GEORGE. M. G. 1961 Diurnal Variations in Two Shallow Ponds in Delhi, India Hydro-Biologia. 18 (3) $265-273$

[10] DAVIS.C.C 1973 A Seasonal Quantitative Study Of the Phytoplankton of Bauline Long Pond, A New Found LandLake. Le Naturaliste Can. 100: 85-105

[11] SHRINIVASAN A. R. SUNDER RAJ and T. Franklin 1973 Diurnal and Seasonal Changes in a Productive Shallow Tropical Pond. Phykos. 12 (1-2): 86-103

[12] SHARMA. K. P., P. K. GOEL \& B. GOPAL 1972 Lymnological Studies Of Polluted Fresh Water. Physio-Chemical Characteristics. Int. J. Ecol. Environ. Sci. 4: 89-105

[13] SCHOL.Z.O 1990 Physico- Chemistry and Vegetation of Piccaninnie Ponds. A Coastal Aquifer-Fed Pond in South-Eastern South Aust. J. Mar. Fresh. Res. 41: 237-246

[14] VENKATESHWARALU. V. P. T. SAMPATHKUMAR \& J. NIRMALKUMARI 1990 Ecology of Algae in the River Moosi, Hyderabad- A Comprehensive Study J. Environ. Biol 11 (1): 79-91

[15] RAI. H. \& G. HILL 1982 On The Nature of The Ecological Cycle Of Lago Jananari: A central Amazonian. Rai/ Varzea. Tropical. Ecol. 23 (1) : 1-50

[16] RAI. H. 1979 Glucose in Fresh Water of CentralAmazonLakes: Natural Substrate Concentrations. Determined by Dilution Of Bioassay. Int. Revue. ges. Hydrobiol 64 (1): 141-146 